\title{
PENGEMBANGAN MODEL SUPERVISI MENGGUNAKAN APLIKASI SEDERHANA VERSI GAJAH MADA UNTUK MENINGKATKAN SNP DI SMA NEGERI 21 MAKASSAR
}

\author{
Madalle Agil ${ }^{1}$, R. Nurhayati ${ }^{2}$ \\ ${ }^{1}$ Dosen IAIM/Pengawas, Jl. Bulukunyi No.12, Sinjai \\ ${ }^{2}$ Dosen IAIM Sinjai, Persatuan Raya Kompleks Ruko, Sinjai \\ Korespondensi penulis, Email: madalleagil@yahoo.co.id; rnurhayati1984@gmail.com
}

\begin{abstract}
Abstrak
Penelitian ini bertujuan membantu Sekolah dalam meningkatkan atau pemberdayaan sumber daya untuk memenuhi Standar Nasional Pendidikan (SNP) lebih khusus lagi untuk mencapai akreditasi Sekolah semaksimal mungkin. Penelitian ini merupakan Penelitian Tindakan Sekolah. PTS adalah penelitian yang dilaksanakan oleh peneliti di sekolah untuk membuat peneliti lebih profesional terhadap pekerjaannya, memperbaiki praktik-praktik kerja, dan melakukan inovasi sekolah serta mengembangkan ilmu pengetahuan terapan (professional knowledge). Pendekatan penelitian yaitu naturalistik-kualitatif, subjeknya sekolah yang ditentukan secara purposive yaitu SMAN 21 Makassar, peneliti bersifat insider (partisipatif) dengan hipotesis dengan aplikasi sederhana versi Gajah Mada SMAN 21 Makassar dapat meningkatkan SNP sekolahnya. Pengambilan data dilakukan dengan pengamatan selama 1 tahun melalui proses dan hasil yang diperoleh sekolah.sementara analisis data dilakukan dengan reduksi, paparan dan simpulan

Hasil penelitian menunjukkan Aplikasi Gajah Mada dapat meningkatkan hasil SNP SMAN 21 Makassar. Dari datapun hasil pemanfaatan aplikasi ini terbukti sangat membantu tugas Pengawas, Kepala Sekolah dan Tim Penjaminan mutu sekolah terutama pemetaan 8 SNP sebagai upaya meningkatkan pemenuhan mutu pendidikan. Hasil analisis dan rekomendasi dari aplikasi telah dimanfaatkan kepala sekolah untuk membuat program sekolah dengan skala prioritas. Hasil analisis pemantauan 8 SNP menunjukkan adanya peningkatan pemenuhan standar dari terakreditasi A (90) tahun 2014 menjadi terakreditasi A $(94,35)$ di tahun 2019.

Penilaian Kinerja Guru terbukti sangat membantu Pengawas dan Kepala Sekolah dalam memetakan kompetensi kinerja guru binaanya. Sejak tahun 2017 SMA Negeri 21 Makassar telah memanfaatkan Aplikasi Penilaian Kinerja. Semua guru telah dinilai secara formatif sebagai langkah awal pembinaan dan pada akhir tahun dinilai secara sumatif. Hasli penilaian kinerja guru merupakan nilai kredit guru pada unsur pembelajaran. Selanjutnya hasil penilaian kinerja guru dimanfaatkan oleh guru dan kepala sekolah sebagai nilai capaian angka kredit tahunan. Penilaian kinerja yang dilakukan secara benar menjadi motivasi guru untuk meningkatkan kompetensinya sehingga standar proses akan meningkat secara signifikan.

Kesimpulannya bahwa pemanfaatan aplikasi berbasis microsoft excel versi gajah mada terbukti sangat membantu sekolah mengembangkan tata kelola sekolah. Pada akhir tahun 2019 diharapkan SMA Negeri 21 Makassar dapat meningkatkan pemenuhan 8 Standar Nasional Pendidikan. Akreditasi SMA Negeri 21 Makassar meningkat dari nilai 90 dengan predikat terakrteditasi A menjadi 94, 35 dengan predikat terakreditasi A tertinggi di Provinsi Sulawesi Selatan. Rekomendasi tulisan ini: pertama, aplikasi pemantauan 8 standar nasional pendidikan harus dikembangkan lagi dan direvisi sesuai dengan peraturan yang berlaku pada tahun pelajaran berjalan. Saat ini menggunakan Perangkat akreditasi SMA/MA tahun 2017 berdasarkan Keputusan Kepala Balitbang Kemendikbud No. 4 /H/AK/2017. Kedua, aplikasi penilaian hasil belajar siswa harus direvisi ulang berdasarkan
\end{abstract}




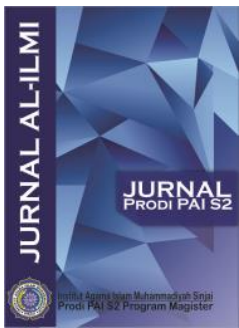

\section{JURNAL AL-ILMI}

Volume 01 No 012020

ISSN (print) : :xxxx-xxxx

ISSN (online) : xxxx-xxxx

Homepage : http://journal.iaimsinjai.ac.id/index.php/al

peraturan yang berlaku yaitu Permendikbud No. 23 tahun 2016 tentang Penilaian Hasil Belajar oleh Satuan Pendidikan.

Kata Kunci : Pengawas, SNP, Aplikasi Sederhana, Sekolah 


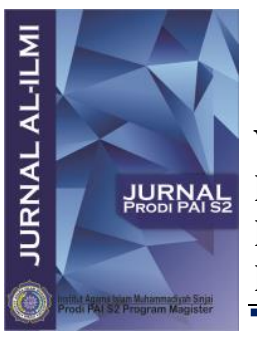

\title{
JURNAL AL-ILMI
}

Volume 01 No 012020

ISSN (print) : $\mathrm{xxxx-xxxx}$

ISSN (online) : $x x x x-x x x x$

Homepage : http://journal.iaimsinjai.ac.id/index.php/al

\begin{abstract}
This research aims to assist schools in increasing or empowering resources to meet National Education Standards (NES) more specifically to achieve School accreditation as much as possible. This research is a school action research (SAR). SAR is research carried out by researchers in schools to make researchers more professional in their work, improve work practices, and innovate schools and develop applied knowledge (professional knowledge). The research approach is naturalisticqualitative, the subject of the school being determined purposively is SMAN 21 Makassar, researchers are insider (participatory) with a hypothesis with a simple application of the Gajah Mada version of SMAN 21 Makassar that can increase the school NES. Data is collected by observing for 1 year through the process and results obtained by the school. While data analysis is done by reduction, exposure and conclusions

The results showed the Gajah Mada application can improve the NES results of SMAN 21 Makassar. From the data also the results of the use of this application proved to be very helpful in the task of Supervisors, School Principals and School Quality Assurance Teams especially the mapping of $8 \mathrm{NES}$ as an effort to improve the fulfillment of the quality of education. The results of the analysis and recommendations from the application have been used by principals to make school programs with priority scale. The results of the monitoring analysis of 8 NES showed an increase in compliance with standards from accredited A (90) in 2014 to accredited A (94.35) in 2019.

Teacher Performance Assessment proved to be very helpful for Supervisors and School Principals in mapping the performance competencies of their supervised teachers. Since 2017 SMAN 21 Makassar has utilized the Performance Appraisal Application. All teachers have been formally assessed as the initial step of coaching and at the end of the year are summatively assessed. Teacher performance assessment results are teacher credit scores on the learning element. Furthermore, the results of the teacher performance appraisal are used by teachers and principals as an annual credit score. Performance appraisals that are carried out correctly motivate teachers to improve their competence so that the standard of the process will increase significantly.

The conclusion is that the use of an application based on Microsoft Excel version of Gajah Mada has proven to be very helpful for schools in developing school governance. By the end of 2019 it is expected that SMAN 21 Makassar can improve the fulfillment of 8 NES. Accreditation of SMAN 21 Makassar increased from a value of 90 with the title of accredited A to 94, 35 with the highest accredited A title in South Sulawesi Province. Recommendations for this paper: first, the monitoring application of 8 national education standards must be further developed and revised in accordance with the regulations in force in the current school year. Currently using the 2017 SMA/MA accreditation kit based on the Decree of the Head of the Indonesian Ministry of Education and Culture No. 4/H/AK/2017. Second, the application for evaluating student learning outcomes must be revised based on the applicable regulations, namely Permendikbud No. 23 of 2016 concerning Assessment of Learning Outcomes by the Education Unit.
\end{abstract}

Keywords: Supervisor, NES, Simple Application, School 


\section{Latarbelakang Masalah}

Masalah kualitas pendidikan di SMAN 21 Makassar masih pada masalah prinsipil. Pertama, sekolah mengalami kesulitan menganalisis hasil pemantauan 8 Standar Nasional Pendidikan (SNP) sebagai dasar untuk pembinaan guru dan pegawai sehingga dapat meningkatkan pemenuhan 8 SNP. Kedua, sekolah tidak melakukan penilaian kinerja dengan benar, penilaian kinerja guru dibuat tidak berdasarkan indikator capaian kompetensi sehingga guru tidak tahu kelemahan kinerjanya. Ketiga, sekolah kesulitan untuk mentranfer hasil penilaian kinerja guru ke angka kredit dengan tepat. Keempat, banyak guru yang tertunda naik pangkat karena alasan kesulitan menyusun Daftar usulan penilaian angka kredit guru dan kesulitan cara menghitungnya. Kelima, Kesulitan perhitungan P2KP bagi guru-guru dan pegawai. Penilain prestasi kerja pegawai dianggap rumit karena ada target, sasaran kerja estimasi waktu dan estimasi biaya.

Mutu sekolah biasanya diukur menggunakan hasil akreditasi. Hasil Akreditasi merupakan hasil standar kualitatif dari instrumen SNP. SNP merupakan keriteria terendah yang harus dipenuhi sekolah dalam melayani peserta didik di seluruh wilayah Negara Kesatuan Republik Indonesia, seperti yang tertuang dalam PP No. 19 tahun 2005. Tujuan SNP adalah menjamin mutu pendidikan nasional dalam rangka mencerdaskan kehidupan bangsa, membentuk watak serta peradaban bangsa yang bermartabat. Selanjutnya SNP selalu disempurnakan secara terencana, terarah, dan berkelanjutan sesuai dengan tuntutan perubahan kehidupan lokal, nasional, maupun global.

Ada 8 (delapan) SNP, 4 SNP yang diperuntukkan bagi guru yaitu Standar Kompetensi Lulusan (SKL), Standar Isi (SK/KD), Standar Proses, Standar Penilaian dan 4 SNP yang diperuntukkan bagi sekolah, yang terdiri dari Standar Pendidik dan Tenaga Kependidikan (PTK), Standar Sarana dan Prasarana, Standar Pengelolaan dan Standar Pembiayaan. Untuk mengukur tingkat pemenuhan 8 SNP dapat dilakukan pemetaan mutu. Instrumen pemetaan 8 SNP dapat merujuk pada Peraturan Menteri Pendidikan Nasional Nomor 004/H/AK/2017 tentang Kriteria dan Instrumen Akreditasi SMA/MA dan Petunjuk Teknis Akreditasi Sekolah. Badan Akreditasi Nasional Sekolah/ Madrasah tahun 2017 sebagai revisi atas Permendiknas nomor 105 tahun 2014.

Hasil pemetaan SNP berdasarkan nilai akreditasi SMA Negeri 21 Makassar pada tahun 2014 (dokumen akreditasi sekolah) menunjukkan pemenuhan 8 SNP sudah maksimal tetapi pergantian Kepala Sekolah pada awal tahun 2019 tentu membawa dampak, sementara Akreditasi Sekolah dilaksanakan pada agustus tahun 2019.

Gambar 1. Hasil Akreditasi SMAN 21 Makassar tahun 2014 


\section{JURNAL AL-ILMI}

Volume 01 No 012020

ISSN (print) : :xxxx-xxxx

ISSN (online) : $x x x x-x x x x$

Homepage : http://journal.iaimsinjai.ac.id/index.php/al

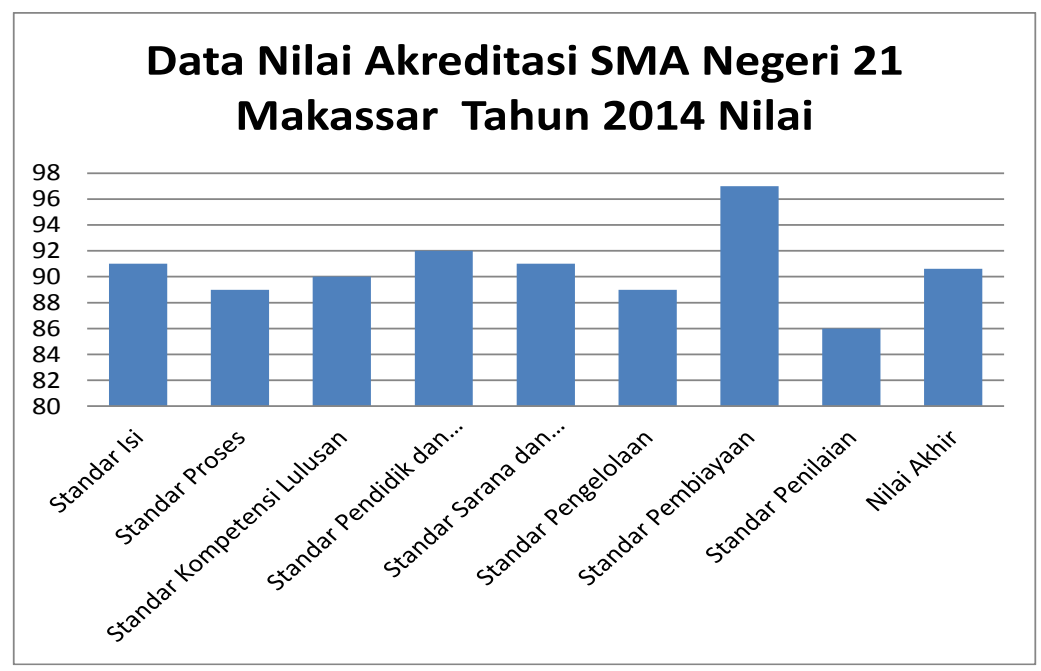

Standar sarana dan prasarana serta standar penilaian masih sangat rendah. Sementara untuk standar isi, standar proses dan standar kompetensi lulusan juga belum maksimal masih pada nilai mutu B. Kekuatan SMA Negeri 21 Makassar ada pada standar pendidik dan tenaga kependidikan serta standar pembiayaan, namun untuk standar pengelolaan dan standar proses juga masih perlu ditingkatkan lagi.

Disamping data tersebut, Kepala Sekolah didampingi oleh Pengawas Pembina dan Asesor Kotamadya Makassar melakukan evaluasi diri. Evaluasi Diri menggunakan instrumen Akreditasi berdasarkan Permendikbud No. 004/H/AK/2017 tentang Petunjuk teknis pengisian Instrumen Akreditasi Sekolah Menengah/Aliyah tanggal 10 Maret 2017. Evaluasi diri SMAN 21 pada bulan Desember 2018 berdasar hasil analisis mutu yang dilakukan oleh pengawas menunjukkan perbaikan pada standar mutu pendidikan terutama standar proses, tetapi standar pengelolaan dan standar penilaian masih paling rendah.

Berdasarkan permasalahan diatas maka dapat dirumuskan permasalahan utamanya adalah apakah pengembangan aplikasi sederhana versi Gajah Mada berbasis excel dapat meningkatkan pemenuhan 8 SNP? Adapun tujuannya yaitu meningkatkan nilai akreditasi SMA Negeri 21 Makassar melalui pengelolaan/tata kelola pengembangan aplikasi sederhana versi gajah mada yang berbasis microsoft excel dalam rangka pemenuhan 8 SNP.

Supervisi merupakan kegiatan yang merupakan tugas dan fungsi utama seorang pengawas. Jenis supervisi pengawas ada dua yaitu supervisi akademik dan supervisi manajerial. Salah satu tugas pokok pengawas adalah melakukan pemantauan dan pengevaluasian 8 Standar Nasional Pendidikan (SNP) di sekolah binaan. Permasalahan terbesar yang dihadapi sekolah adalah bagaimana sekolah mampu mencapai 8 SNP secara efektif dan efisien. Setiap sekolah mengharapkan untuk memenuhi pelaksanaan 8 SNP dalam rangka peningkatan nilai akreditasi, sebagai standar mutu suatu sekolah. Masalah besar yang dihadapi SMAN 21 Makassar adalah obyektivitas penilaian yang dilakukan Kepala Sekolah, demikian juga dengan kepedulian Pendidik dan Tenaga Pendidik terhadap pemenuhan 8 Standar Nasional Pendidikan (SNP) masih belum optimal.

Atas dasar itu diperlukan aplikasi yang terbuka dan sederhana yang bisa digunakan untuk meningkatkan 8 SNP SMAN 21 Makassar khususnya terkait Pendidik dan Tenaga Kependidikan (PTK). Aplikasi yang dikembangkan adalah Aplikasi 8 Standar Nasional Pendidikan. Diharapkan melalui pemanfaatan dan pendampingan pada sekolah binaan di 


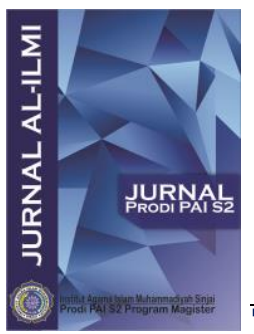

\section{JURNAL AL-ILMI}

Volume 01 No 012020

ISSN (print) : $x x x x-x x x x$

ISSN (online) : $x x x x-x x x x$

Homepage : http://journal.iaimsinjai.ac.id/index.php/al

SMA Negeri 21 Makassar pada kurun waktu Januari 2017 s.d. Juni 2019 terdapat peningkatan pemenuhan 8 Standar Nasional Pendidikan. Nilai Akreditasi SMA Negeri 21 Makassar meningkat secara signifikan dari A dengan skor 91 tahun 2014 menjadi A dengan skor 94, 85 tahun 2019.

\section{Aplikasi SNP versi Gajah Mada}

Aplikasi versi Gajah Mada merupakan aplikasi sederhana berbasis excel yang dapat digunakan oleh pengawas dan kepala sekolah dalam melakukan kegiatan supervisi terutama terkait dengan pemenuhan 8 standar nasional pendidikan (SNP) di sekolah sesuai dengan permendikbud No. 004/H/AK/2017. Pemanfaatan aplikasi versi Gajah Mada bertujuan membantu pengawas dan kepala sekolah dalam menjalankan salah satu tupoksinya. Adapun pengembangan Aplikasi Gajah Mada untuk pemantauan 8 SNP.

Dalam rangka akreditasi sekolah perlu adanya persiapan-persiapan yang matang khususnya dokumen-dokumen kegiatan pengembangan sekolah yang terdokumentasi dan tertata rapi. Persiapan awal akreditasi sekolah tentunya menyiapkan instrumen akreditasi. Intrumen akreditasi disusun berdasarkan Peraturan Menteri Pendidikan dan Kebudayaan Nomor 004/H/AK/2017 tentang Kriteria dan Instrumen Akreditasi SMA/MA Petunjuk Teknis Akreditasi Sekolah. Badan Akreditasi Nasional Sekolah/ Madrasah. 2017. Instrumen akreditasi disajikan dalam bentuk hard copy dan soft copy, Analisis pemantauan 8 SNP dapat menggunakan Aplikasi Pemantauan 8 SNP. Pemantauan dilaksanakan oleh kepala sekolah didampingi pengawas pembina dan asesor. Hasil analisis pemantauan 8 SNP berupa rekomendasi yang dijadikan acuan pembuatan program sekolah tahun mendatang. Secara rinci pemanfaatan aplikasi ini yang telah kami laksanakan di SMAN 21 Makassar sebagaimana pada bagian hasil laporan ini.

Hasil PK guru dimaksudkan bermanfaat untuk menentukan berbagai kebijakan yang terkait dengan peningkatan mutu dan kinerja guru sebagai ujung tombak pelaksanaan proses pendidikan dalam menciptakan peserta didik yang cerdas, komprehensif, dan berdaya saing tinggi. PK Guru merupakan acuan bagi sekolah/madrasah untuk menetapkan pengembangan karir dan promosi guru. Bagi guru, PK Guru merupakan pedoman untuk mengetahui unsurunsur kinerja yang dinilai dan merupakan sarana untuk mengetahui kekuatan dan kelemahan individu dalam rangka memperbaiki kualitas kinerjanya. Secara rinci pemanfaatan aplikasi ini yang telah kami laksanakan di SMAN 21 Makassar sebagaimana pada hasil laporan ini.

Aplikasi ini dapat digunakan oleh pengawas sebagai intrumen pemantauan 8 standar nasional pendidikan atau digunakan oleh kepala sekolah sebagai instrumen evaluasi diri sekolah. Instrumen ini dikembangkan berdasarkan Peraturan Menteri Pendidikan dan Kebudayaan Nomor 004/H/AK/2017 tentang Kriteria dan Instrumen Akreditasi SMA/MA Petunjuk Teknis Akreditasi Sekolah. Badan Akreditasi Nasional Sekolah/ Madrasah. 2017. Aplikasi ini terdiri dari 6 menu, yaitu :

\section{a. Menu Utama}

Menu utama terdiri dari tabel menu dan input data sekolah serta asesor/pengawas jika digunakan oleh pengawas. Pengisian data cukup pada kolom yang berwarna putih, yaitu: 


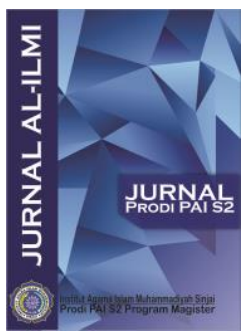

\section{JURNAL AL-ILMI}

Volume 01 No 012020

ISSN (print) : $x x x x-x x x x$

ISSN (online) : $x x x x-x x x x$

Homepage : http://journal.iaimsinjai.ac.id/index.php/al

identaitas pengawas, identitas sekolah, identitas kepala sekolah dan keterangan lainnya. Dari menu utama untuk pindah ke menu lain cukup klik tabel merah sebelah kanan sesuai kebutuhan dan langsung link ke menu yang tertulis.

Gambar1: Menu utama Aplikasi Pemantauan 8 SNP

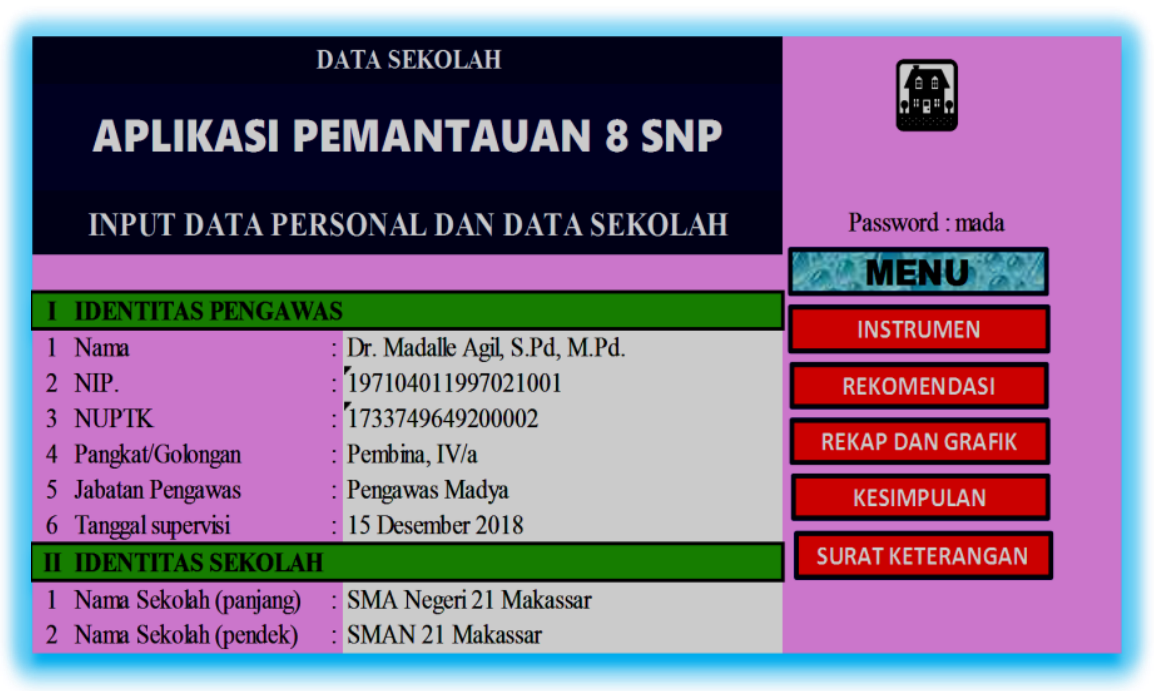

\section{b. Instrumen penilaian}

Menu instrumen penilaian dikembangkan berdasarkan instrumen akreditasi permendikbud 004/H/AK/2017. Instrumen ini berisikan form penilaian 8 standar nasional pendidikan terdiri dari 129 item penilaian yaitu: Standar isi no. 1 s.d. 9, standar proses no. 10 s.d. 30, standar kompetensi lulusan no. 31 s.d. 37, standar pendidik dan tenaga kependidikan no. 38 s.d.56, standar sarana dan prasarana no. 57 s.d. 80 , standar pengelolaan no. 81 s.d. 95 , standar pengelolaan no. 96 s.d. 111 dan standar penilaian no. 112 s.d 129.

Cara pengisian dengan menceklis kolom jawaban A,B,C,D atau E sesuai kondisi nyata yang ada di sekolah dengan merujuk pada buku pedoman yang ada.

\section{c. Rekomendasi}

Rekomendasi adalah hasil analisis data secara kualitatif dan kuantitatif pada menu intrumen akreditasi. Dari sheet data instrumen penilaian data diolah sesuai kriteria berdasarkan buku pedoman penilaian akreditasi dan hasilnya berupa rekomendasi. Pada menu rekomendasi terdiri dari nomor urut, pernyataan, kondisi ideal, kondisi nyata, kesenjangan dan rekomendasi. Rekomendasi berisikan apa yang akan dilakukan berdasarkan kesenjangan yang ada.

\section{d. Rekap dan Grafik}

Dari input data data diolah secara kuantitatif dan disajikan rekap hasil pengolahan data dalam bentuk tabel dan grafik.

Gambar 2: Grafik dan rekap hasil pemantauan 8 SNP. 


\section{JURNAL AL-ILMI}

Volume 01 No 012020

ISSN (print) : $x x x x-x x x x$

ISSN (online) : $x x x x-x x x x$

Homepage : http://journal.iaimsinjai.ac.id/index.php/al

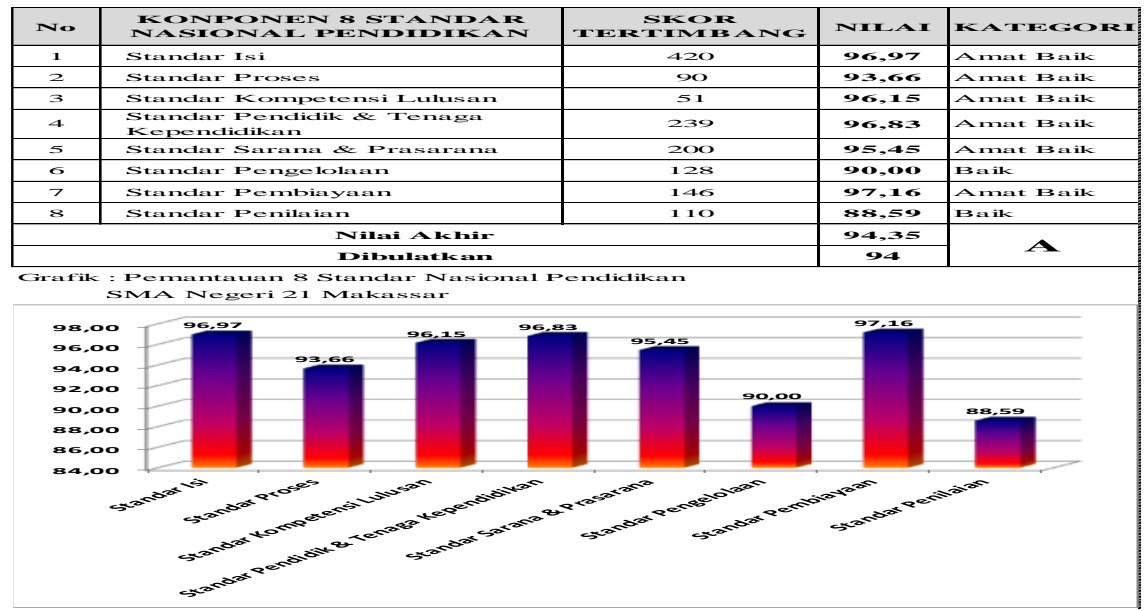

\section{e. Kesimpulan}

Kesimpulan didasarkan pada hasil analisis data secara kualitatif dan disajikan secara kuantitatif . Untuk tindak lanjut dituliskan secara manual dari hasil kesimpulan pelaksanaan pemantauan 8 standar nasional pendidikan.

\section{f. Surat Keterangan}

Surat keterangan diperlukan jika pengawas yang akan melakukan penilaian di sekolah binaan. Jika aplikasi ini digunakan intern oleh sekolah surat keterangan tidak diperlukan. Surat keterangan ini menerangkan bahwa pengawas pembina telah melakukan pemantauan pada sekolah binaan, dibuat oleh kepala sekolah.

\section{g. Penggunaan Aplikasi}

Aplikasi ini digunakan SMA Negeri 21 Makassar dan SMA lainnya. Di SMA Negeri 21 Makassar digunakan sejak pertengahan tahun 2017 s.d. pertengahan tahun 2019 sebagai alat evaluasi diri sekolah dalam rangka upaya pemenuhan 8 standar pendidikan nasional dan peningkatan nilai akreditasi SMA Negeri 21 Makassar pada pertengahan tahun 2019.

\section{Keunggulan Aplikasi SNP versi Gajah Mada}

Pemanfaatan aplikasi microsoft excel versi Gajah Mada untuk Pemantauan 8 SNP memiliki beberapa keunggulan, diantaranya:

1) Program aplikasi mudah tanpa instalasi dan langsung dapat digunakan.

2) Proteksi aplikasi bisa di buka atau ditutup oleh siapa saja (open/off)

3) Menginput data sederhana hanya menggunakan ceklis pada kolom yang sesuai.

4) Hasil input data langsung dianalisis oleh sistem menghasilkan rekomendasi.

5) Dilengkapi dengan output rekap nilai dan grafik hasil pemantauan

6) Instrumen berdasarkan Peraturan Menteri Pendidikan dan Kebudayaan Nomor 004/H/AK/2017 tentang Kriteria dan Instrumen Akreditasi SMA/MA serta Petunjuk Teknis Akreditasi Sekolah oleh Badan Akreditasi Nasional Sekolah/ Madrasah tahun 2017

\section{Hasil Capaian SNP dengan Aplikasi Gajah Mada}




\section{JURNAL AL-ILMI}

Volume 01 No 012020

ISSN (print) : :xxxx-xxxx

ISSN (online) : $x x x x-x x x x$

Homepage : http://journal.iaimsinjai.ac.id/index.php/al

Hasil pemanfaatan aplikasi penilaian selama 2 tahun, terdapat peningkatan kompetensi guru dalam penilaian dan meningkatkan standar penilaian sekolah. Pemanfaatan aplikasi ini telah diteliti melalui penelitian tindakan selama 4 semester dan hasilnya standar penilaian meningkat tiap semesternya. Penilaian kinerja guru telah dilaksanakan dengan benar dan sesuai petunjuk berdasarkan permendiknas nomor 35 tahun 2010. Semua guru telah mendapatkan penilaian kinerja dan telah ditransfer ke dalam penilaian angka kredit guru seperti pada tabel berikut.

Tabel peningkatan Hasil SNP SMAN 21 Makassar setelah menggunakan aplikasi versi Gajah Mada

\begin{tabular}{|c|l|c|c|}
\hline \multirow{2}{*}{ No Komponen } & \multicolumn{2}{c|}{ Tahun } \\
\cline { 3 - 4 } & & $\mathbf{2 0 1 4}$ & $\mathbf{2 0 1 9}$ \\
\hline 1 & Standar Isi & 91 & $\mathbf{9 6 , 9 7}$ \\
\hline 2 & Standar Proses & 89 & $\mathbf{9 3 , 6 6}$ \\
\hline 3 & Standar Kompetensi Lulusan & 90 & $\mathbf{9 6 , 1 5}$ \\
\hline 4 & Standar Pendidik \& Tenaga Kependidikan & 92 & $\mathbf{9 6 , 8 3}$ \\
\hline 5 & Standar Sarana dan Prasarana & 91 & $\mathbf{9 5 , 4 5}$ \\
\hline 6 & Standar Pengelolaan & 88 & $\mathbf{9 0 , 0 0}$ \\
\hline 7 & Standar Pembiayaan & 96 & $\mathbf{9 7 , 1 6}$ \\
\hline $\mathbf{8}$ & Standar Penilaian & $\mathbf{8 6}$ & $\mathbf{8 8 , 5 9}$ \\
\hline & Nilai Akhir & 91 & $\mathbf{9 4 , 3 5}$ \\
\hline & Kategori Akreditasi & $\mathrm{A}$ & $\mathrm{A}$ \\
\hline
\end{tabular}

Dari hasil pemanfaatan aplikasi penilaian selama 2 tahun terdapat penigkatan kompetensi guru dalam penilaian dan meningkatkan standar penilaian sekolah. Pemanfaatan aplikasi ini telah diteliti melalui penelitian tindakan selama 4 semester dan hasilnya standar penilaian meningkat tiap semesternya. Penilaian kinerja guru telah dilaksanakan dengan benar dan sesuai petunjuk berdasarkan permendiknas nomor 35 tahun 2010. Semua guru telah mendapatkan penilaian kinerja dan telah ditransfer ke dalam penilaian angka kredit guru.

Perubahan hasil evaluasi 8 SNP sebelum menggunakan aplikasi dengan setelah menggunakan aplikasi versi gajah mada sangat signifikan meningkat. Secara khusus dijelaskan perubahan SNP setelah aplikasi gajah mada digunakan yaitu

\section{Standar Isi}

Hasil pemantauan pada standar isi dengan 9 pernyataan tertutup diperoleh: amat baik pada pelaksanaan pengembangan perangkat pembelajaran pada kompetensi sikap spiritual, amat baik pada pelaksanaan pengembangan perangkat pembelajaran pada kompetensi sikap sosial siswa, amat baik pada pelaksanaan pengembangan perangkat pembelajaran pada kompetensi pengetahuan siswa, amat baik pada pelaksanaan pengembangan perangkat pembelajaran pada kompetensi keterampilan siswa, amat baik pada sekolah mengembangkan perangkat pembelajaran sesuai dengan tingkat kompetensi dan ruang lingkup materi pembelajaran, amat baik pada Kepala sekolah/madrasah bersama guru mengembangkan kurikulum sesuai dengan pedoman pengembangan KTSP dengan melibatkan beberapa unsur, amat baik pada Sekolah/madrasah menyusun KTSP 
yang meliputi 6 unsur, amat baik pada Sekolah/madrasah mengembangkan kurikulum sesuai dengan prosedur operasional pengembangan KTSP yang meliputi 4 tahapan, baik pada Sekolah/madrasah melaksanakan kurikulum sesuai 5 ketentuan.

\section{Standar Proses}

Nilai pantauan pada standar proses dengan 21 pernyataan tertutup meliputi: amat baik pada Sekolah/madrasah mengembangkan silabus yang memuat 9 komponen, amat baik pada Sekolah/madrasah mengembangkan RPP dari silabus, secara lengkap dan sistematis, amat baik pada Sekolah/madrasah mengalokasikan waktu dan beban belajar sesuai ketentuan, amat baik pada Sekolah/madrasah melaksanakan proses pembelajaran dengan jumlah siswa per rombongan belajar maksimum 36 orang, amat baik pada Siswa menggunakan buku teks pelajaran dalam proses pembelajaran, amat baik pada Guru melakukan pengelolaan kelas yang baik, baik pada Guru memulai pembelajaran dengan 5 langkah pendahuluan, amat baik pada Guru menggunakan model pembelajaran yang sesuai dengan karakteristik siswa dan mata pelajaran, amat baik pada Guru menggunakan metode pembelajaran yang sesuai karakteristik siswa dan mata pelajaran, amat baik pada Guru menggunakan media pembelajaran yang sesuai karakteristik siswa dan mata pelajaran, amat baik pada Guru menggunakan sumber belajar yang sesuai karakteristik siswa dan mata pelajaran, amat baik pada Guru menggunakan pendekatan pembelajaran yang sesuai karakteristik siswa dan mata pelajaran, amat baik pada Guru bersama siswa mengakhiri pembelajaran, baik pada Guru menggunakan pendekatan penilaian otentik dalam penilaian proses pembelajaran, amat baik pada Guru memanfaatkan hasil penilaian otentik untuk merencanakan program, amat baik pada Kepala sekolah/madrasah melakukan pengawasan proses pembelajaran dengan objektif dan transparan guna peningkatan mutu secara berkelanjutan, amat baik pada Kepala sekolah/madrasah melakukan supervisi proses pembelajaran terhadap seluruh guru setiap tahun, amat baik pada Kepala sekolah/madrasah memantau proses pembelajaran, amat baik pada Kepala sekolah/madrasah menindaklanjuti hasil supervisi proses pembelajaran amat baik pada Kepala sekolah/madrasah menyusun: (1) laporan pemantauan, (2) laporan supervisi, (3) laporan evaluasi proses pembelajaran, (4) program tindak lanjut, baik pada tindak lanjut hasil pengawasan pembelajaran.

\section{Standar Kompetensi Lulusan}

Peningkatan nilai pada standar kompetensi lulusan dengan 7 pernyataan tertutup adalah: amat baik pada pengalaman belajar siswa dalam pengambilan keputusan, amat baik pada analisis pemecahan masalah siswa pada mapel iptek, amat baik pada kemampuan siswa menganalisis gejala alam, amat baik pada sumber belajar siswa, baik pada pembiasaan mencari informasi, amat baik pada pemanfaatan lingkungan secara produktif, amat baik pada kegiatan seni budaya siswa.

\section{Standar Pendidik dan Tenaga Kependidikan}

Pengembangan hasil pada standar pendidik dan tenaga kependidikan dengan 19 pernyataan tertutup yaitu: sudah memenuhi persyaratan kualifikasi akademik, sudah memenuhi persyaratan dengan latar belakang pendidikan, amat baik pada kehadiran guru, amat baik pada pelaksanaan KBM sesuai dengan prinsip prinsip pembelajaran, baik pada integritas guru, baik pada telah melaksanakan komunikasi efektif, amat baik pada penguasaan pembelajaran, memenuhi persyaratan kepala sekolah, memenuhi 
kualifikasi akademik kepala sekolah, memenuhi pengalaman mengajar kepala sekolah, memenuhi kemampuan manajerial kepala sekolah, memenuhi kemampuan kewirausahaan kepala sekolahj, sudah melakukan sepervisi, sudah memiliki kualifikasi untuk tenaga administrasi, memenuhi syarat untuk latar belakang tenaga administrasi, sudah memiliki sertifikasi kompetensi pustakawan, sudah memiliki kualifikasi minimal pustakawan, sudah memiliki kualifikasi minimal laboran, memenuhi syarat untuk latar belakang pendidikan laboran,

\section{Standar Sarana dan Prasarana}

Perkembangan mutu pada standar Sarana Prasarana dengan 28 pernyataan tertutup yaitu: sesuai ketentuan luas lahan sekolah, memenuhi persyaratan akses keselamatan darurat untuk letak lokasi sekolah, memenuhi persyaratan untuk sarana untuk meningkatkan kenyamanan, memenuhi persyaratan untuk kepemilikan tanah sesuai peraturan perundangan, memenuhi persyaratan untuk luas minimal lantai bangunan, memenuhi persyaratan untuk sistem kebakaran dan petir, memenuhi persyaratan untuk sanitasi sekolah, memenuhi persyaratan untuk ventilasi udara dan pencahayaan, memenuhi persyaratan untuk ruang kelas, sudah ada ruang perpustakaan, baik pada ruang laboratorium biologi, memenuhi persyaratan untuk ruang laboratorium fisika,cukup dan memenuhi syarat untuk ruang laboratorium kimia, tidak memiliki ruang komputer/TIK, cukup dan memenuhi syarat untuk ruang laboratorium bahasa, cukup dan memenuhi syarat untuk ruang laboratorium fisika, cukup dan memenuhi syarat untuk ruang laboratorium kimia, cukup dan memenuhi syarat untuk ruang laboratorium komputer, cukup dan memenuhi syarat untuk ruang laboratorium bahasa, cukup dan memenuhi syarat untuk ruang kepala sekolah, cukup dan memenuhi syarat untuk ruang guru, cukup dan memenuhi syarat untuk ruang tata usaha, cukup dan memenuhi syarat untuk tempat ibadah, cukup dan memenuhi syarat untuk ruang bimbingan konselng, cukup dan memenuhi syarat untuk ruang UKS/M, cukup dan memenuhi syarat untuk ruang organisasi, cukup dan memenuhi syarat untuk jamban siswa, cukup dan memenuhi syarat untuk gudang.

\section{Standar Pengelolaan}

Hasil penilaian pada standar Pengelolaan dengan 16 pernyataan tertutup yaitu: baik pada rumusan visi sekolah, baik pada rumusan misi sekolah, baik pada rumusan tujuan sekolah, baik rencana kerja tahunan, baik pedoman pengelolaan secara tertulis,baik struktur organisasi, baik pelaksanaan kegiatan, baik kegiatan kesiswaan, baik kegiatan pengembangan kurikulum, baik program pendayagunaan pendidik, baik pada pengelolaan sarpra, ada pada pengelolaan pembiayaan, baik pada kegiatan untuk menciptakan suasana nyaman, baik pada kegiatan kemitraan, baik pada kegiatan program pengawasan, baik pada kegiatan evaluasi diri.

\section{Standar Pembiayaan}

Perbaikan pantauan pada standar Pembiayaan dengan 16 pernyataan tertutup yaitu: lengkap untuk dokumen investasi sarpras, kategori baik pada pengembangan 
berdasarkan RKA, kategori baik pada memiliki modal kerja. Kategori baik pada membayar gaji guru, kategori baik pada membayar gaji tenaga kependidikan, kategori baik pada belanja biaya kegiatan. Kategori baik pada belanja kesiswaan, kategori baik pada belanja pengadaan alat, kategori baik pada belanja pengadaan bahan habis pakai. Kategori baik pada alokasi kegiatan rapat, perjalanan dinas, kategori baik pada pengadaan soal-soal, kategori baik pada belanja pengadaan daya dan jasa. Kategori baik pada belanja kegiatan operasional, kategori baik pada pengelolaan sumbangan masyarakat.

\section{Standar Penilaian}

Perubahan hasil pemantauan pada standar Penilaian dengan 13 pernyataan tertutup disimpulkan: baik pada penjelasan instrumen penilaian, amat baik pada prosedur penilaian, pengembangan teknik penilaian, penggunaan teknik penilaian. Amat baik pada pengolahan teknik penilaian, pengembalian hasil pemeriksaan pekerjaan siswa, perbaikan pembelajaran. Amat baik pada laporan hasil belajar siswa, penilaian sikap dan kepribadian, amat baik pada ulangan tengah semester. Amat baik pada kriteria kenaikan kelas, penentuan nilai akhir kelompok mata pelajaran, dan baik pada penyelenggaraan ujian sekolah.

\section{Dampak penggunaan aplikasi di sekolah binaan}

Aplikasi Gajah Mada dapat meningkatkan hasil SNP SMAN 21 Makassar, sehingga dapat sekolah lain dapat memanfaatkannya pula. Dari datapun hasil pemanfaatan aplikasi ini terbukti sangat membantu tugas Pengawas, Kepala Sekolah dan Tim Penjaminan mutu sekolah terutama pemetaan 8 SNP sebagai upaya meningkatkan pemenuhan mutu pendidikan. Hasil analisis dan rekomendasi dari aplikasi telah dimanfaatkan kepala sekolah untuk membuat program sekolah dengan skala prioritas. Hasil analisis pemantauan 8 SNP menunjukkan adanya peningkatan pemenuhan standar dari terakreditasi A (90) tahun 2014 menjadi terakreditasi A $(94,35)$ di tahun 2019.

Penilaian Kinerja Guru terbukti sangat membantu Pengawas dan Kepala Sekolah dalam memetakan kompetensi kinerja guru binaanya. Sejak tahun 2017 SMA Negeri 21 Makassar telah memanfaatkan Aplikasi Penilaian Kinerja. Semua guru telah dinilai secara formatif sebagai langkah awal pembinaan dan pada akhir tahun dinilai secara sumatif. Target penilaian untuk semua guru telah dilaksanakan dengan baik sesuai peraturan perundangan yang berlaku. Hasli penilaian kinerja guru merupakan nilai kredit guru pada unsur pembelajaran. Selanjutnya hasil penilaian kinerja guru dimanfaatkan oleh guru dan kepala sekolah sebagai nilai capaian angka kredit tahunan. Penilaian kinerja yang dilakukan secara benar menjadi motivasi guru untuk meningkatkan kompetensinya sehingga standar proses akan meningkat secara signifikan.

Dari uraian diatas disimpulkan bahwa pemanfaatan aplikasi berbasis microsoft excel versi gajah mada terbukti sangat membantu sekolah mengembangkan tata kelola sekolah. Pada akhir tahun 2019 diharapkan SMA Negeri 21 Makassar dapat meningkatkan pemenuhan 8 Standar Nasional Pendidikan. Akreditasi SMA Negeri 21 Makassar meningkat 


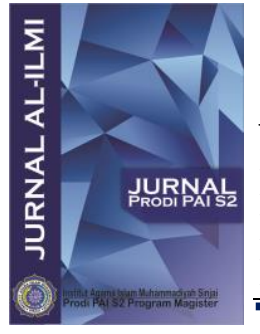

\section{JURNAL AL-ILMI}

Volume 01 No 012020

ISSN (print) : :xxxx-xxxx

ISSN (online) : $x x x x-x x x x$

Homepage : http://journal.iaimsinjai.ac.id/index.php/al

dari nilai 90 dengan predikat terakrteditasi A menjadi 94, 35 dengan predikat terakreditasi A tertinggi di Provinsi Sulawesi Selatan.

Rekomendasi tulisan ini adalah pertama aplikasi pemantauan 8 standar nasional pendidikan harus dikembangkan lagi dan direvisi sesuai dengan peraturan yang berlaku pada tahun pelajaran berjalan. Saat ini menggunakan Perangkat akreditasi SMA/MA tahun 2017 berdasarkan Keputusan Kepala Balitbang Kemendikbud No. 4 /H/AK/2017. Kedua, aplikasi penilaian hasil belajar siswa harus direvisi ulang berdasarkan peraturan yang berlaku yaitu Permendikbud No. 23 tahun 2016 tentang Penilaian Hasil Belajar oleh Satuan Pendidikan.

\section{Daftar Pustaka}

\section{Peraturan Perundang Undangan:}

Undang-undang Nomor 20 Tahun 2003 Tentang Sistem Pendidikan Nasional.

Undang-undang Nomor 5 Tahun 2014 Tentang Aparatur Sipil Negara

Peraturan Pemerintah Nomor 13 Tahun 2015 Tentang Perubahan Kedua atas Peraturan Pemerintah Nomor 19 Tahun 2005 tentang Standar Nasional Pendidikan.

Peraturan Pemerintah Nomor 46 tahun 2011 tentang Penilaian Prestasi Kerja Pegawai Negeri Sipil.

Peratuan Kepala BKN Nomor 1 tahun 2013 tentang Pelaksanaan Peraturan Pemerintah nomor 46 tahun 2011.

Peraturan Menteri Pendidikan dan Kebudayaan Republik Indonesia Nomor 20 tahun 2016 tentang Standar Kompetensi Lulusan

Peraturan Menteri Pendidikan dan Kebudayaan Republik Indonesia Nomor 21 tahun 2016 tentang Standar Isi

Peraturan Menteri Pendidikan dan Kebudayaan Republik Indonesia Nomor 22 tahun 2016 tentang Standar Proses

Peraturan Menteri Pendidikan dan Kebudayaan Republik Indonesia Nomor 23 tahun 2016 tentang Standar Penilaian

Peraturan Menteri Pendidikan dan Kebudayaan Republik Indonesia Nomor 24 tahun 2016 tentang Standar Kompetensi dan Kompetensi Dasar

Peraturan Menteri Pendidikan dan Kebudayaan Republik Indonesia Nomor 59 tahun 2014 tentang Kurikulum 2013 SMA/MA

Permendikbud RI No. 004/H/AK/2017 tentang Standar Nasional Pendidikan

Petunjuk Teknis Akreditasi Sekolah. Badan Akreditasi Nasional Sekolah/ Madrasah. 2017

\section{Buku:}

Aedi, Nur. 2014. Pengawasan Pendidikan, Tinjauan Teori Dan Praktik, Penerbit Raja Grafindo Persada. Jakarta

J. Priansa, Doni.dan R. Somad. 2014. Manajemen Supervisi dan Kepemimpinan Kepala Sekolah. Penerbit Alfabeta. Bandung

Lantip D.P. dan Sudiyono, 2011. Supervisi Pendidikan, Penerbit Gava Media Yogyakarta, hlm. 88-90. 


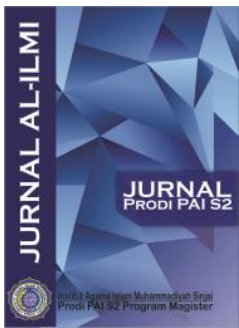

\section{JURNAL AL-ILMI}

Volume 01 No 012020

ISSN (print) : :xxxx-xxxx

ISSN (online) : $x x x x-x x x x$

Homepage : http://journal.iaimsinjai.ac.id/index.php/al

Nur Aedi, 2014. Pengawasan Pendidikan, Tinjauan Teori Dan Praktik, Penerbit Raja Grafindo Persada, Jakarta hlm. 55.

Piet A. Sahertain, 2008. Konsep Dasar Dan Teknik Supervisi Pendidikan, Penerbit Rineka Cipta, Jakarta, hlm. 35-42.

Romadhon, W.E. 2017. Pemenuhan Stndar Penilaian Melalui Pendampingan dan Pengembangan Aplikasi Penilaian versi Why di SMA Negeri 13 OKU. PTS.

Suhardan, Dadang. 2010. Supervisi Profesional. Penerbit Alfabeta. Bandung. Hal. 43 
Volume 01 No 012020

ISSN (print) : :xxxx-xxxx

ISSN (online) : $x x x x-x x x x$

Homepage : http://journal.iaimsinjai.ac.id/index.php/al 


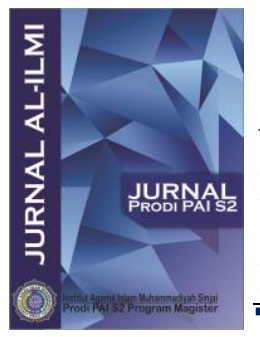

\section{JURNAL AL-ILMI}

Volume 01 No 012020

ISSN (print) : $x x x x-x x x x$

ISSN (online) : $x x x x-x x x x$

Homepage : http://journal.iaimsinjai.ac.id/index.php/al

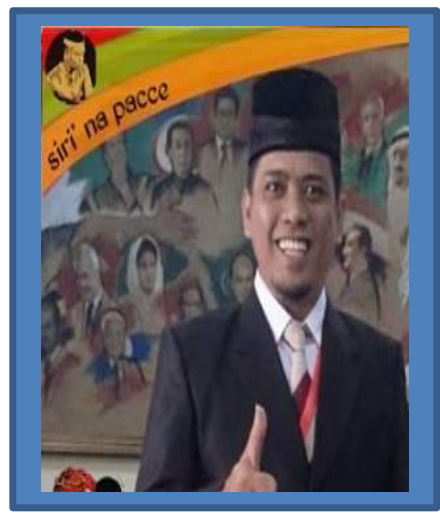

\section{RIWAYAT HIDUP SINGKAT}

Madalle Agil dilahirkan di Cakke, 1 April 1971. Tingkat Pendidikan dari SD sampai SMA ditamatkan di Cakke Kabupaten Enrekang Provinsi Sulawesi Selatan. Setelah tamat dari SMA Muhammadiyah Cakke tahun 1989 melanjutkan pendidikan di Institut Keguruan dan Ilmu Pendidikan (IKIP) Ujung Pandang. Fakultas Pendidikan Ilmu Pengetahuan Sosial (FPIPS) Jurusan Pendidikan Geografi. Selama Kuliah di IKIP Ujung Pandang berhasil memperoleh Beasiswa prestasi.

Demikian pula Aktif dalam berbagai Organisasi Kemahasiswaan baik internal Kampus maupun organisasi eksternal kampus. Setelah tamat tahun 1996, mendaftar Pendidikan Magister Jurusan Magister Transportation Planning di Australia, lewat beasiswa URGE, namun gagal berangkat karena beasiswa dibayarkan hanya $50 \%$ sesuai jurusan yang dipilih waktu itu. Diawal tahun 1997 tepatnya 17 Januari diangkat menjadi CPNS di SMA Negeri 3 Herlang Kabupaten Bulukumba. Tahun 2002 melanjutkan Pendidikan Magister di Universitas Negeri Makassar Jurusan Manajemen Pendidikan dan tamat pada tahun 2004. Kemudian Pada tahun 2012 Memperoleh Beasiswa dari Pemerintah Provinsi Sulawesi Selatan lewat Program 5000 Doktor, dan diterima di Universiti Teknology Malaysia (UTM Malaysia) tetapi karena sesuatu hal akhirnya mengundurkan diri. Dan mendaftar di Program Pascasarjana Universitas Hasanuddin jurusan Administrasi Publik. Selesai Program Doktor di Unhas pada tahun 2017.

Karir menjadi pegawai negeri sipil diawali di SMA Negeri 1 Herlang Kabupaten Bulukumba tahun 1997. Pada tahun 2005 pindah ke SMA Negeri 2 Sinjai. Tujuh tahun mengabdi di SMAN 2 Sinjai, pada tahun 2012 dimutasi menjadi Pengawas SMP dan SMA Kabupaten Sinjai. Jadi sudah 6 tahun berprofesi sebagai pengawas Sekolah SMA.

Berbagai prestasi akademik yang pernah saya peroleh, yaitu: Tahun 2004 mendapat predikat Guru Teladan 3 Kabupaten Bulukumba. Guru Berprestasi 1 Kabupaten Sinjai tahun 2009 dan tahun yang sama sebagai Guru Berprestasi 4 Tingkat Provinsi Sulawesi Selatan. Beberapa karya dan penghargaan telah dicapai selama berkarir sebagai guru. Tahun 2009 mendapat penghargaan Satya Lencana X tahun dari Presiden. Sejak tahun 1997 aktif mengikuti beberapa kegiatan kompetisi keguruan tingkat nasional diantaranya, tahun 2000 sebagai peserta Lomba Keberhasilan Guru dalam Pembelajaran Tingkat Nasional. Pada tahun 2002 sebagai Finalis Lomba Integrasi Iptek dan Imtag Tingkat Nasional. Pada tahun 2010 terpilih sebagai peserta R n D program Seameo Qitep di Bandung dan ditunjuk sebagai president. Menulis Beberapa buku dan Modul Pembelajaran, serta Karya nonfiksi yang dilombakan di tingkat Provinsi. Dari rangkaian prestasinya pada tahun 2015 mendapat predikat Pengawas berprestasi 1 tingkat Kabupaten Sinjai sekaligus Finalis tingkat Provinsi Sulawesi Selatan. Kemudian Pada Tahun 2017 Berhasil juara 1 Pengawas Berprestasi tingkat Provinsi Sulawesi Selatan. Sekaligus tahun yang sama menjadi finalis Pengawas Berprestasi Tingkat Nasional. Kemudian tahun 2019 ini terpilih lagi menjadi juara 1 Pengawas SMA Berprestasi Tingkat Provinsi Sulawesi Selatan. Dan berhak berkompetisi di pemilihan Pengawas SMA Berprestasi tingkat Nasional. Aktif juga menjadi Narasumber dan partisipan dalam seminar dan workshop tingkat internasional, nasional terlebih lagi di tingkat provinsi dan kabupaten.

Sejak awal Juni 2013 menjabat sebagai Pengawas Sekolah Madya Mata Pelajaran Geografi wilayah Sinjai, berbagai tantangan dalam menjalankan tugas, terutama geografis wilayah Sinjai dari pegunungan, daratan sampai kepulauan. Tetapi dengan semangat pengabdian dan profesionalitas, justru itu menjadi vitamin 


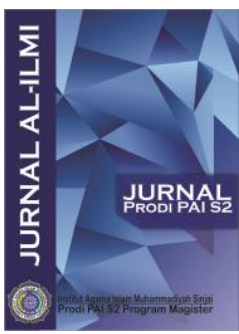

\section{JURNAL AL-ILMI}

Volume 01 No 012020

ISSN (print) : :xxxx-xxxx

ISSN (online) : $x x x x-x x x x$

Homepage : http://journal.iaimsinjai.ac.id/index.php/al

untuk meningkatkan mutu sekolah, bersama para gurunya. Dengan keikhlasan menjalankan tugas dan melakukan yang terbaik. Maka hambatan dan tantangan geografis tidak dirasakan, bahkan justru itu yang mengantarkan saya menjadi pengawas berprestasi 2 kali.

Untuk meningkatkan kompetensi diri turut berbagi ilmu disela waktu rutinitas sebagai Pengawas SMA di beberapa Kampus di Sinjai diantaranya IAIM Sinjai, STISIPM Sinjai, STIPM Sinjai, IAIN Bone sebagai Dosen Luar Biasa dari tahun 2005 sampai sekarang. Motto: PENGAWAS MAJU KARENA ADA KEPALA SEKOLAH HEBAT, KEPALA SEKOLAH HEBAT KARENA ADA GURU BERPRESTASI. PENGAWAS MAJU, HEBAT SEMUA 


\section{JURNAL AL-ILMI}

Volume 01 No 012020

ISSN (print) : $x x x x-x x x x$

ISSN (online) : $x x x x-x x x x$

Homepage : http://journal.iaimsinjai.ac.id/index.php/al

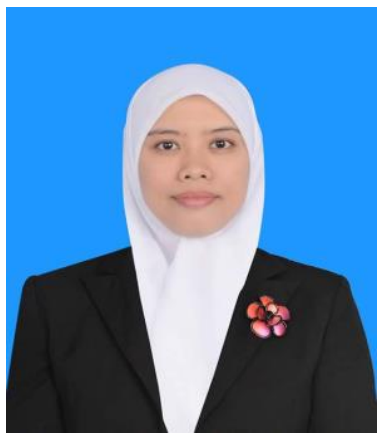

R. Nurhayati, dilahirkan di Palu, 19 Juli 1984. Pada tahun 1996, pindah ke Kabupaten Sinjai. Tingkat Pendidikan dari SD sampai SMA ditamatkan di Kabupaten Sinjai Provinsi Sulawesi Selatan. Setelah tamat dari SMA 2002 melanjutkan pendidikan di Sekolah Tinggi Agama Islam (STAIM) Sinjai dan tamat tahun 2010.

Selama menempuh kuliah jenjang S1, Aktif dalam berbagai Organisasi Kemahasiswaan baik internal Kampus maupun organisasi eksternal kampus. Diantaranya yakni Badan Eksekutif Mahasiswa (BEM) STAIM Sinjai, PK. IMM Sinjai, KSR PMI Unit 001 STAIM Sinjai, Kwarda Hizbul Wathan kabupaten Sinjai, Tahun 2013 melanjutkan Pendidikan Magister di Universitas Muhammadiyah (Unismuh) Makassar Jurusan Manajemen Pendidikan Islam dan tamat pada tahun 20015. Pada saat kuliah S2 ini, mendapatkan Beasiswa penyelesaian dari Kementrian Agama RI.

Mengawali karier pada tahun 2010 sebagai pegawai tetap STAIM Sinjai, ditempatkan pada posisi staff bagian perpustakaan. Setelah menamatkan Pascasarjana tahun 2015, lalu mendaftarkan diri sebagai dosen tetap Prodi PAI di tahun itu pula mendapatkan SK dosen tetap dan terdaftar sebagai dosen tetap hingga sekarang. Pada tahun 2016, dilantik sebagai sekretaris Prodi pada Pendidikan Agama Islam (PAI) Fakultas Tarbiyah dan Ilmu Keguruan IAIM Sinjai hingga sekarang. 